\title{
Neuro-ophthalmology Internet digital media library
}

\author{
Beau B. Bruce, MD
}

Fred Bernard ${ }^{1}$ once said that one picture is worth a thousand words. If that is the case, then how many is a video worth? A collection arranged by Dr. Shirley H. Wray gives you the opportunity to contemplate this question. She has organized a unique peer-reviewed, Web-accessible database of neurologic and neuroophthalmologic texts, images, and videos designed to educate practitioners, students, and patients. The archives are part of the Neuro-Ophthalmology Virtual Education Library, which has been formed by a collaboration between the North American Neuro-Ophthalmology Society and the Spencer S. Eccles Health Sciences Library at the University of Utah.

Dr. Wray's collection reflects a unique approach to organizing the enormous number of cases she has collected over the course of her career, an approach made possible only by the remarkable advances in information technology. Users of the site are able to browse the case collection by two methods: 1) diagnosis or 2) symptoms and signs. This vastly increases the potential uses of the collection. When approaching the collection by diagnosis, one can actually see a real patient with findings that we have all found difficult to visualize while reading a textbook. While seeing a patient with a given diagnosis, the site can help you see subtle signs that may not be appreciated until you take a second look. When looking at cases from a symptom or sign approach, residents and other physicians can use it to look up information on the often bewildering but common neurologic symptoms that face them in clinic each day. This has the virtue of transforming the cases into educational materials. The visitor is able to approach a case as mystery to be solved, thus increasing not only exposure to the eye's intimate association with the brain but analytical ability as well.

In addition, the site has another layer of depth that further increases its potential: Dr. Wray has given each case standardized metadata including anatomy, pathology, neuroimaging, neuropathology, etiology, and treatment, with references to the literature and to other sources for further information. The site has been made so accessible that patients can use it themselves. In one extraordinary case, a mother from Canada noted intermittent eye movements in her baby. As we can all imagine, she was frustrated by trying to explain an unusual, intermittent sign to her physicians, and she had difficulty in getting the response that any appropriately concerned mother would expect. However, she stumbled across Dr. Wray's collection and found a case that looked exactly like her son's condition. She was able to bring this to Dr. Wray's attention and was referred by Dr. Wray immediately to a specialist in Toronto for an appropriate evaluation of her child.

As we are all so apt to say in medicine, no patient is ever quite like the textbook, but on this site the patients form the textbook and you get to join a revered neuro-ophthalmologist for rounds. Many neurologists have already found this site to be an invaluable teaching resource for students, residents, and themselves. It is a unique opportunity to explore the fascinating world of neuroophthalmology. During the most cursory visit, you will find not only something that will amaze you, but something that will teach you as well. So surf on over to http://medstat.med.utah.edu/ NOVEL. There you will find Dr. Wray's collection and the collections of other notable neuroophthalmologists. Not only will it stimulate every afferent and efferent neuron of your visual system, you will be learning more than you can possibly find in a row of textbooks about how it works. 


\title{
Neurology
}

\author{
Neuro-ophthalmology Internet digital media library \\ Beau B. Bruce \\ Neurology 2006;67;E10 \\ DOI 10.1212/01.wnl.0000233994.65758.c9
}

This information is current as of September 11, 2006

Updated Information \&

Services

Subspecialty Collections

Permissions \& Licensing

Reprints including high resolution figures, can be found at: http://n.neurology.org/content/67/5/E10.full

This article, along with others on similar topics, appears in the following collection(s):

All Imaging

http://n.neurology.org/cgi/collection/all_imaging

All Neuro-ophthalmology

http://n.neurology.org/cgi/collection/all_neuroophthalmology

Information about reproducing this article in parts (figures,tables) or in its entirety can be found online at:

http://www.neurology.org/about/about_the_journal\#permissions

Information about ordering reprints can be found online:

http://n.neurology.org/subscribers/advertise

Neurology ${ }^{\circledR}$ is the official journal of the American Academy of Neurology. Published continuously since 1951, it is now a weekly with 48 issues per year. Copyright. All rights reserved. Print ISSN: 0028-3878. Online ISSN: 1526-632X.

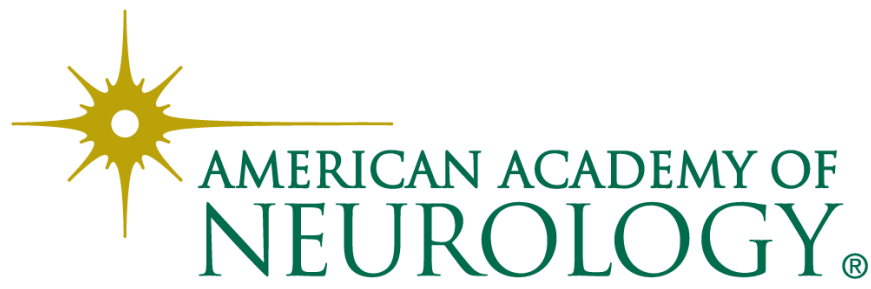

